\title{
Prediction Equations for Black Spruce Seed Production and Dispersal in Northern Ontario
}

\author{
B. Payandeh ${ }^{1}$ \\ and
}

V. F. Haavisto ${ }^{1}$

\begin{abstract}
Nonlinear regression equations were developed to describe seed production and dispersal in black spruce (Picea mariana [Mill.]B.S.P.)in northern Ontario. Solution of the equations can provide useful information beyond the range of the original data, because of the flexibility of the models used. For example, solution of equations 1.3 indicates that cones from intermediate crown class trees initially have about twice as many seeds as those of either the dominant or codominant trees, but disperse their seeds at a much faster rate. Average number of seeds per cone for all three crown classes is about 7 after 10 years. Older cones of the in. termediate crown class trees have fewest seeds per cone. Solution of equation 4 indicates that average seed viability is about $53 \%$ and decreases only slightly during the first three years. It then decreases very rapid. ly up to 12 years to about $5 \%$. Similarly, equations 6 and 7 may be solved to determine an optimum strip-cut width for sufficient seedfall across the strip to produce satisfactory regeneration.
\end{abstract}

\section{Résumé}

On a élaboré des équations de régression non linéaire en vue de décrire la production de graines chez l'épinette noire (Picea mariana [Mill.] B.S.P.) et leur dispersion dans des tourbières du nord de l'Ontario. La solution des équations peut fournir des renseignements plus utiles que les données de départ à cause de la souplesse des modèles utilisés. Par exemple, la solution des équations 1 à 3 indique que les cônes provenant d'une classe de cime intermédiaire possèdent au départ deux fois plus de graines que ceux des dominants ou les codominants, mais qu'ils dispersent leurs graines beaucoup plus rapidement. Le nombre moyen de graines par cône, pour les trois classes de cime, est d'environ 7 après 10 ans. Les vieux cônes de la classe de cime intermédiaire sont ceux qui ont le moins de graines. La solution de l'équation 4 indique que la visibilité moyenne des graines est d'environ $53 \%$ et qu'elle diminue très peu au cours des trois premières années. Elle décroît ensuite très rapidement jusqu'à 12 ans où elle atteint $5 \%$. De la même façon, on peut se servir des équations 6 et 7 pour déterminer la largeur optimale des bandes de coupe afin d'assurer une bonne dispersion des graines dans ces bandes et une régénération satisfaisante. ${ }^{1}$ Canadian Forestry Service, Great Lakes Forest Research Centre, Sault Ste. Marie, ON.
P6A 5M7.

\section{Introduction}

Black spruce (Picea mariana [Mill.] B.S.P.) is the most important pulpwood species in Ontario. Because harvesting is approaching the limits of the annual allowable cut, much emphasis has been placed on regeneration of black spruce cutovers. Natural renegeration of black spruce on large clearcuts that have been mechanically harvested is often inadequate, particularly on upland sites (Fraser et al. 1975, Haavisto 1980). Planting bare-root or container stock has met with only partial success (Anon. 1974) and has become very expensive. Operational direct seeding of black spruce has generally been a failure (Scott 1966, Waldron 1974). Some possible reasons for failure of natural regeneration and direct seeding are as follows: inadequate quantity and/or quality of seed, limited seed dispersal, wrong season of seed application, adverse weather, inadequate site preparation, loss of seed to erosion and seed eaters, and competition from weeds.

Almost $50 \%$ of the black spruce in northern Ontario occurs on peatland sites (Ketcheson and Jeglum 1972). Recent studies have indicated that natural regeneration of black spruce on peatland is not as problematic as that on uplands (Robinson 1974, Fraser et al. 1975) but that adequate stocking $(60 \%)$ is as yet obtained only on a small portion of the total areas cut (Haavisto 1980). Cutting modifications, including strip cutting, to improve natural regeneration have been tried over the past several years with varying degrees of success. It has been shown that site preparation techniques can be effective in helping to establish black spruce on some site types (Haavisto 1979).

As the cost of planting increases, so does the need to develop either successful natural regeneration or direct seeding combined with appropriate site preparation. Two critical factors affecting natural or modified regeneration methods in black spruce are seed production and dispersal. Unfortunately, relatively little information is available on these important factors (Howard 1970, Schooley and Hall 1979).

Haavisto (1975) provides preliminary information on the above factors. However, because of natural variation in the data, graphical and tabular presentation of the results limit their usefulness and application somewhat.

The purpose of this note is to present regression equations developed for describing black spruce seed production and seed dispersal based on Haavisto's (1975) work and on some additional data. Owing to the form and flexibility ${ }^{2}$ of

\footnotetext{
${ }^{2}$ Nonlinear regression models fit most biological data as well as or better than their linear counterparts. If properly chosen, non-linear models are more flexible than linear models, i.e., they do not produce meaningless or unreasonable results upon extrapola. tion. Nonlinear curve fitting is basically an iterative procedure in which the initial parameter estimates of the model are changed until the mean residual error ap. proaches least squares approximation. Most educational and scientific computing centres now have one or more nonlinear regression routines in their scientific statistical packages (Payandeh, B. 1981. Application of nonlinear regression models in forestry. Unpublished manuscript).
} 
the nonlinear regression models employed, the resulting equations may be extrapolated beyond the range of the original data, thereby providing additional information not readily attainable from the tabular data. Such equations may be used for prediction of seed production and dispersal of a given stand and thus be useful as a management decisionmaking tool. In addition, such equations are essential for simulation studies and other analytical aspects of black spruce regeneration. Model forms developed here may be applied in other areas of forestry research such as regeneration, stand establishment and development.

\section{Analysis and Results}

Haavisto (1975) described data collection and other details of this study. Briefly, data on seed production were collected from black spruce in three crown classes: dominant, co-dominant, and intermediate. The total number of cones (all ages) per dominant-tree was almost three times the number of cones per tree in either the co-dominant or the intermediate crown class trees. The number of seeds per cone in the intermediate trees, however, was about twice as high as that in the dominant trees, while the number of seeds per cone in the co-dominant trees was about midway between those of the other two crown classes. About two-thirds of all seeds were empty, i.e., lacking the capacity to germinate, and the remaining one-third were filled or potentially viable.

Graphical presentation of the data indicated that the cones dispersed some of their potentially viable seeds and many of their empty seeds during the first five to six years. Intermediate crown class trees lost a greater proportion of their seeds during this period than did the dominant and codominant trees. In general the total number of seeds per cone decreased very rapidly (exponentially) during the first six years, then gradually levelled off at four seeds per cone for cones older than 20 years. This type of relationship, like many others such as reduction in stand density and mortality as a function of stand age, may be well expressed by the so-called simple exponential decay function as:

$$
\begin{aligned}
Y & =B_{1} e^{-B_{2} X} \\
\text { where: } Y & =\text { number of seeds per cone } \\
X & =\text { age of cone in years } \\
B s & =\text { parameters of the model }
\end{aligned}
$$

The data on total number of seeds per cone were thus fitted to the simple exponential decay function expressing total number of seeds per cone as a function of cone age for the three crown classes of trees. Table 1 gives the resulting equations which produced a very good fit for the dominant and intermediate crown classes, and a reasonably good fit for the co-dominant trees. Figure 1 clearly indicates that the cones on the intermediate crown class trees initially have almost twice as many seeds as those of either the dominant or the co-dominant trees, but disperse their seeds at a much faster rate. Average total number of seeds per cone for all

Table 1. Regression equations expressing number of seeds per cone as a function of cone age for peatland black spruce trees of different crown classes. ${ }^{a}$

\begin{tabular}{lcccc}
\hline Crown class & Regression equation & $\mathbf{R}^{2}$ & SE & No. \\
\hline Dominant & $Y=15.46 \mathrm{e}^{-.0855 x}$ & 0.97 & 0.44 & $(1)$ \\
Co-dominant & $Y=18.19 \mathrm{e}^{-.1210 x}$ & 0.76 & 2.08 & $(2)$ \\
Intermediate & $Y=34.02 \mathrm{e}^{-.1755 x}$ & 0.94 & 1.92 & $(3)$ \\
\hline
\end{tabular}

a Source of data: Haavisto 1975. Equations are based on 12 observations.

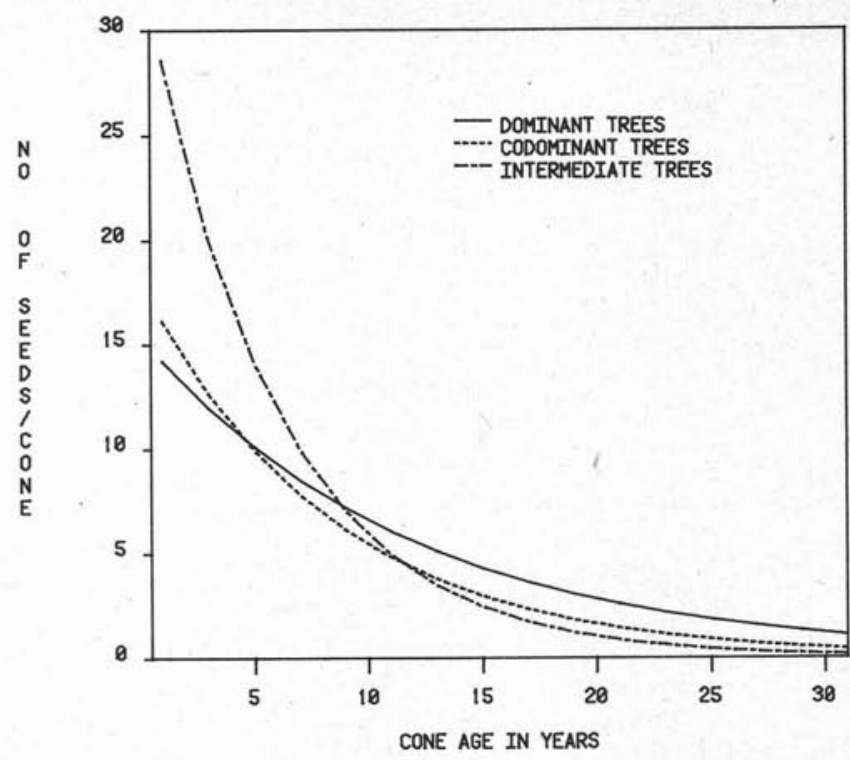

Figure 1 Number of seeds/cone expressed as a function of cone age for peatland black spruce trees for three crown classes.

three crown classes is about 7 after 10 years. For older cones of the intermediate crown class trees, the number of seeds falls below those of the dominant and co-dominant crown classes.

Haavisto (1975) indicated that viability of the filled seeds from the first 5 years averaged about $53 \%$, and dropped sharply (exponentially) between the 6 th and the 10th year, subsequently decreasing to almost nil at 20-25 years. There was very little change in seed viability during the first 3 to 4 years. This type of relationship may be well expressed by an inverse sigmoidal function.

An inverse sigmoidal function may be developed in several ways. One way is simply by subtracting a sigmoidal function from a constant. This was done by subtracting the Richards (1959) growth function from $B_{0}$ as:

$$
Y=B_{0}-B_{1}\left(1-e^{-B_{2} X_{1}} B_{3}\right.
$$

where: $Y=$ independent variable, e.g., percent seed viability

$X=$ dependent variable, e.g., cone age in years

Bs $=$ parameters of the model

$\mathrm{e}=$ base of natural logarithm

In the above model, $\mathrm{B}_{0}$ is the upper asymptote when $\mathrm{X}=0$, and $B_{0}-B_{1}$ gives the lower asymptote when $X \rightarrow \infty$.

The data on percent seed viability were fitted to the above model expressing seed viability as an inverse sigmoidal function of cone age. The model produced an excellent fit to the data (Fig. 2), as evidenced by the following equation;

$$
\begin{array}{r}
Y=56.875-54.71\left(1-e^{-.451 x}\right)^{12.116} \\
R^{2}=.99, \text { SEE }=2.44
\end{array}
$$

Figure 2 clearly indicates that seed viability decreases only slightly during the first three years. It then decreases very rapidly up to 12 years to about $5 \%$. Seed viability in cones 12 years and older decreases gradually and reaches an inverse plateau of about $2 \%$ for cones 25 years and older. 


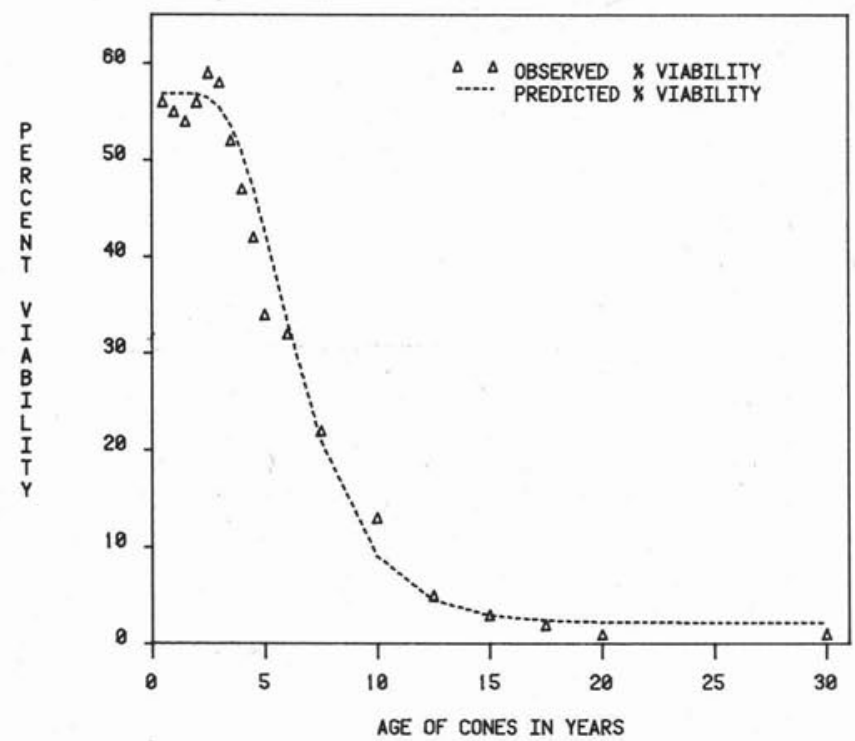

Figure 2 Average viability of black spruce seed expressed as a function of cone age.

Two sets of data on seed dispersal across the stripcuts were available. The first set consisted of a 5-year average annual seedfall across two strips that were $200 \mathrm{~m}$ wide. Both strips were located in Kennedy Twp, Cochrane District in northeastern Ontario, and were oriented east to west. Seedfall was evaluated at intervals of $20 \mathrm{~m}$ across the cutovers. The second set of data consisted of a 3-year average annual seedfall across three stripcuts of different widths $(40,60$, and $100 \mathrm{~m}$ wide) collected at intervals of $5 \mathrm{~m}$. These strips were located in Sangster Twp, Cochrane District, and were oriented north to south. The main purpose for establishing these stripcuts was to determine the rates of seedfall and subsequent regeneration influx in order to establish the optimum width for obtaining adequate natural black spruce regeneration on peatland cutovers.

In the case of the 200-m-wide strips in Kennedy Twp, the data indicated that, except in areas near the edge of the stand, seed dispersal was fairly uniform across the strip, with only minor variations. The second set of data indicated a similar pattern, except that it was clearly evident that the amount of seedfall first rapidly and then gradually decreased as both the strip width and the distance from the edge of the stand increased. This type of relationship may be considered as a family of $U$ shaped curves. To our knowledge, no simple model can describe this type of functional relationship. After considerable model manipulation, the following model, referred to here as the exponential decayexponential model, was developped. It describes the above relationship very well:

$$
Y=B_{1} X_{1} B_{2} e^{-B_{3} X_{2}}+B_{4} X_{1} B_{5} e^{-B_{6} / X_{2}}
$$

where: $Y=$ estimated seedfall/ha

$$
\begin{aligned}
& \mathrm{X}_{1}=\text { strip width in } \mathrm{m} \\
& \mathrm{X}_{2}=\text { distance from stand edge in } \mathrm{m} \\
& \mathrm{Bs}=\text { parameters of the model. }
\end{aligned}
$$

Since seedfall in the two stripcut experiments was significantly different, the two data sets were fitted to the above model separately. ${ }^{3}$ In view of the nature and variability of the data, the resulting two regression equations (Table 2) produced very good fits. Figure 3 gives the graphical presentation of equation 7 , which clearly indicates that seed

\footnotetext{
3 Other data sets-such as those of Howard (1970) may be well expressed by the above
} model form with a somewhat different set of parameter estimates. dispersal is an exponentially decreasing function of distance from both stand edges bordering a stripcut and also a decreasing function of the width of the cut.

\begin{tabular}{|c|c|c|c|c|}
\hline $\begin{array}{l}\text { Direction of } \\
\text { dispersal }\end{array}$ & Regression equation & $\mathbf{R}^{2}$ & SEE & No. \\
\hline $\begin{array}{l}\text { North- } \\
\text { south }^{b}\end{array}$ & $\begin{array}{l}Y^{c}= \\
36329.1 X_{1}^{-.5426} e^{-.0751 X_{2}} \\
\quad+ \\
0.1242 E^{d} 10 X_{1}^{-2.7432} e^{-53.597 / X}\end{array}$ & 0.75 & 338.8 & (6) \\
\hline West-east $^{e}$ & $\begin{array}{l}Y^{f}=239.99 X_{1}-.0574 e^{-.0347 X_{2}} \\
+17501 E 16 X_{1}-5.2562 e^{-578.321}\end{array}$ & 0.86 & 19.4 & (7) \\
\hline
\end{tabular}

Table 2. Regression equations expressing black spruce seed dispersal across stripcut as a function of strip width and distance from the edge of the stand. ${ }^{a}$

a Source of data: Haavisto 1975. Equations 6 and 7 and are based on 20 and 32 observa. tions, respectively.

$b_{\text {Stripcut orientation: east-west. }}$

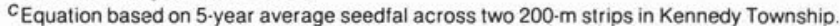

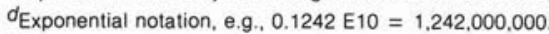

esripcut orientation: north-south.

${ }^{t}$ Equation based on 3-year average seedfall across three stripcuts 40,60 , and $100 \mathrm{~m}$ wide, respectively, in Sangster Township.

Where $Y=$ estimated seedfall/ha

$X_{1}=$ stripcut width in $\mathrm{m}$.

$X_{2}=$ distance from edge of the stand.

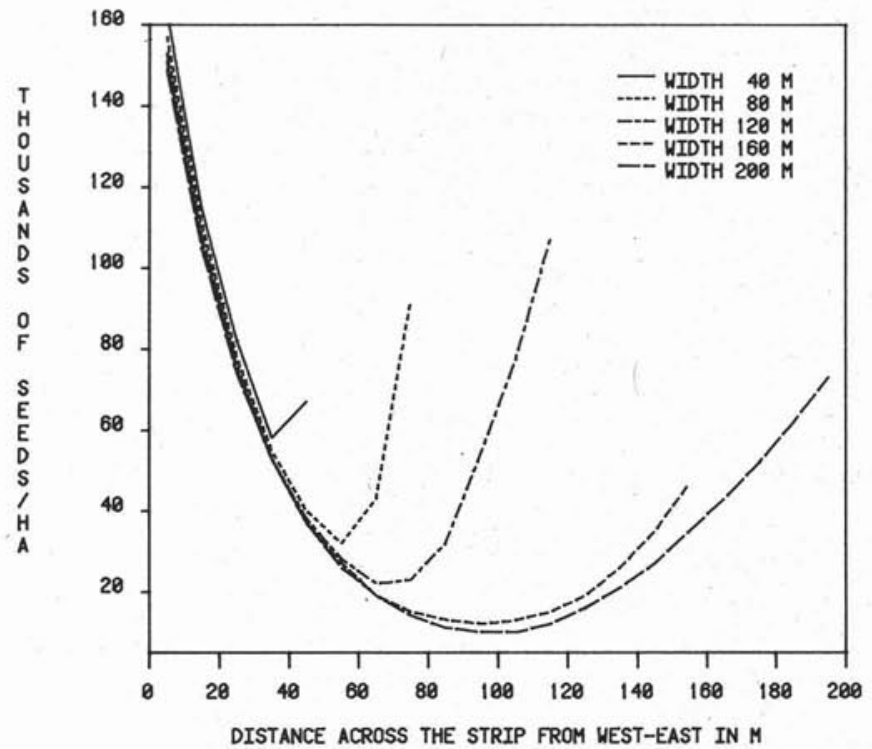

Figure 3 Black spruce strip-cut seed dispersal as a function of strip width and distance from stand edge.

\section{Discussion}

Haavisto (1975) concluded that large quantities of seed are produced annually and dispersed by peatland black spruce in northern Ontario. Although seed dispersal across cutover areas is only a small portion of that falling in the stands, the amount seems adequate for successful regeneration. However, if only a small fraction of the viable seeds is transported far across cutover areas, with a smaller fraction landing on receptive seedbeds and even fewer seeds germinating and surviving, then the resulting regeneration will not necessarily be adequate. 
Table 3. Black spruce stripcut seedfall prediction (1000/ha).

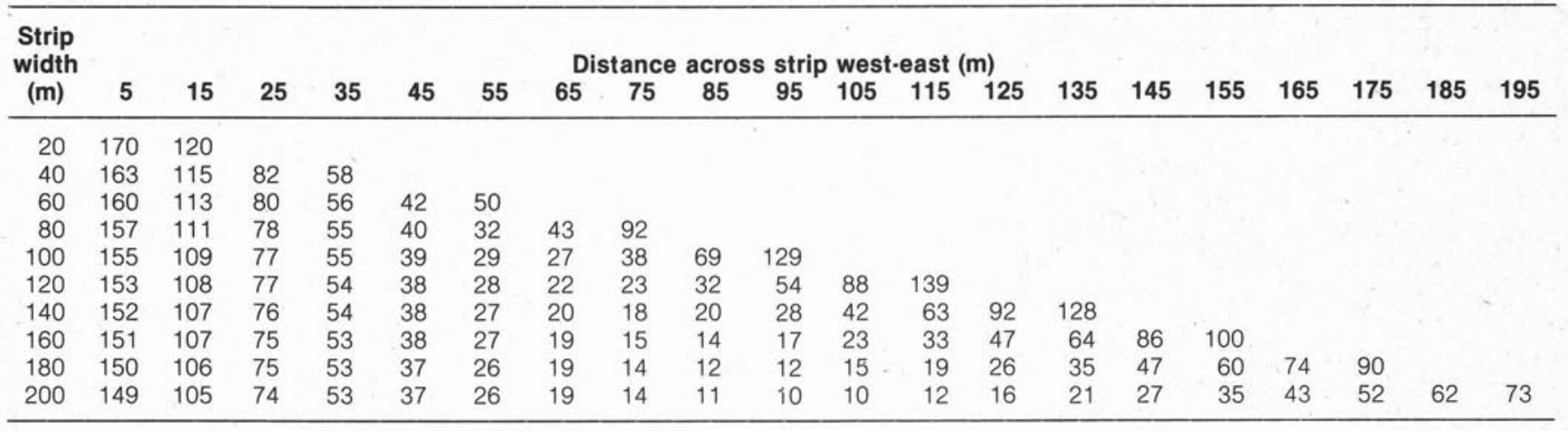

Regression equations developed here describe black spruce seed production and dispersal very well. Because of model flexibility such equations may be extrapolated beyond the range of the original data as shown in Table 3 , thereby providing additional useful information not readily obtained from a graphical presentation of the results. These equations may be solved to provide answers to several practical questions. For example, if it is determined that for practical and/or economic reasons, cones with less than, say, 10 seeds are not worth picking, the solution of equations 1 to 3 (or Fig. 1) indicates that cones 4 years old or younger from dominant or co-dominant trees and cones nearly 7 years old or younger from intermediate trees will meet this criterion. The solution of equation 4 (or Fig. 2) will further indicate, for example, that about $50 \%$ of the 4 -year-old seeds are potentially viable while only about $20 \%$ of the 7 -year-old seeds may be viable. Similarly, equations 6 and 7 may be solved to determine the optimum width of strip which will have a certain amount of seed falling at given distances from the stand edges. The solution of equation 7 for strip widths ranging from $40 \mathrm{~m}$ to $200 \mathrm{~m}$ and distances from the stand edge increasing in $10 \mathrm{~m}$ intervals (Table 3 ) further exemplifies the usefulness of these equations.

As stated earlier, predictive equations such as those developed here can be used as analytical tools for decisionmaking; they are also essential for conducting simulation studies to evaluate regeneration problems in black spruce. Additional information on seed viability, seed dispersal, and subsequent germination and survival is needed to aid in developing practical and economical methods for regenerating black spruce on peatlands in Ontario.

\section{References}

Anonymous. 1974. Survival and growth of the plantations on crown lands in Ontario. Ont. Min. Nat. Resour., Div. For., For. Manage. Br. $15 \mathrm{p}$.

Fraser, J.W., Haavisto, V.F., Jeglum, J.K., Dai, T.S., and Smith, D.M. 1975. Black spruce regeneration on stripcuts and clearcuts in the Nipigon and Cochrane areas of Ontario. Dep. Environ., Can. For. Serv., Sault Ste. Marie, Ont. Report O-X-246. 34 p.

Haavisto, V.F. 1975. Peatland black spruce seed production and dispersal in northeastern Ontario. p. 240-264 in Black Spruce Symposium. Dep. Environ., Can. For. Serv., Sault Ste. Marie, Ont. Symp. Proc. O-P-4

Haavisto, V.F. 1979. Some considerations for regenerating black spruce on peatlands in the Northern Clay Forest Section, Ontario. Dep. Environ., Can. For. Serv., Sault Ste. Marie, Ont. Report O-X-295. 32 p.

Haavisto, V.F. 1980. Seed requirement for regenerating black spruce in Ontario. Dep. Environ., Can For. Serv., Sault Ste. Marie, Ont. For. Res. Newsl., Fall-Winter 1980. p 2-3.

Howard, E.W. 1970. Dissemination and viability of seed from up. land black spruce in central Newfoundland. Dep. Fish. For.. Ottawa, Ont. Bi-mon. Res. Notes 26(3):32.

Ketcheson, D.E. and Jeglum, J.K. 1972. Estimates of black spruce and peatland areas in Ontario. Dep. Environ.. Can. For. Serv., Sault Ste. Marie, Ont. Inf. Rep. O-X-172. 29 p.
Richards, J.F. 1959. A flexible growth function for empirical use. J. Exp. Bot. 10(29):290-300

Robinson, F.C. 1974. A silvicultural guide to the black spruce working group. Ont. Min. Nat. Resour., Div. For., For. Manage. Br. $44 \mathrm{p}$

Schooley, H.O. and Hall, J.P. 1979. Quantity of viable seed re tained in old black spruce cones. Dep. Environ., Can. For. Serv., Ottawa, Ont. Bi-mon. Res. Notes 35(6):32.

Scott, J.D. 1966. A review of direct seeding projects carried out by Ontario Department of Lands and Forests from 1956 to 1964 Ont. Dep. Lands For., Silvic. Notes No. 5. 34 p.

Waldron, R.M. 1974. Direct seeding in Canada, 1900-1972. p. 4-27 in J.H. Cayford, Ed. Direct seeding symposium. Dep. Environ., Can. For. Serv., Ottawa, Ont. Publ. No. 1339.

\section{FACULTY OF FORESTRY UNIVERSITY OF TORONTO}

invites applications for the following two assistant professor positions.

\section{Tenure Stream Position in}

SILVICULTURE AND FOREST BIOLOGY

Duties: Teaching undergraduate and graduate courses in the areas of forest biology, silvics and silviculture, graduate student supervision, administrative responsibilities, and initiating research in silviculture and related forest biology. Research interest in the silviculture of eastern Canadian species is desirable.

Qualifications: $\mathrm{Ph} . \mathrm{D}$. in silviculture or a related discipline required; previous teaching and research experience desirable.

Term Appointment in

WOOD SCIENCE AND FOREST PRODUCTS

Duties: Teaching undregraduate and graduate courses dealing with wood properties, processing and forest products, graduate student supervision, initiating research, and administrative responsabilities.

Qualifications: Ph.D in wood science or a closely released area preferred; relevant teaching, research, and industrial experience would be an asset. Appointment to be made at the rank of assistant professor.

Salary will be commensurate with the qualifications and experience of the successful candidate.

In accordance with Canadian immigration requirements, this advertisement is directed to Canadian citizens and permanent residents.

Interested and qualified individuals should submit a curriculum vitae and other relevant information. Three referees who are ac quainted with the work of the applicant should be asked to forward letters of reference. These should be submitted to:

\author{
The Chairman, Search Committee \\ Faculty of Forestry \\ University of Toronto \\ Toronto, Ontario, Canada, M5S 1 A1
}

